\title{
Determining Football Players Position Using SAW Method
}

\author{
Achmad Jauhari ${ }^{1}$, Ika Oktavia Suzanti ${ }^{2}$, Sigit Susanto Putro ${ }^{3}$, Devie Rosa Anamisa ${ }^{4}$, \\ Mohammad Abdillah ${ }^{5}$, Achmad Khozaimi ${ }^{6}$, Eka Mala Sari Rochman ${ }^{7}$ \\ \{jauhariaja@gmail.com ${ }^{1}$ \} \\ Faculty of Engineering, University of Trunojoyo Madura, Jalan Raya Telang, PO BOX 02 Kamal, \\ Bangkalan $-69162^{1234567}$
}

\begin{abstract}
When entering SSB (Soccer School) a player generally chooses the desired position. However after become a professional, player can change that position. A coach will determine the player's position in game based on player data. This task often makes the coach difficulty in making the right decision by assessing the player objectively. In addition, generally the decision making process still rely on coach instincts. Therefore, with decision support system to determine the position of football players would be very helpful to achieve maximum results in every game. The technology that authors offer is a decision support system in selection player position based on player data using SAW (Simple Additive Weighting) method. The results accuracy of the assessment on this method by $50 \%$, which is from results comparison between calculation system and coach recommendations.
\end{abstract}

Keywords: football school, method, saw, player, decision support system.

\section{Introduction}

Football is one of the most popular sport in the world. Almost all of countries known and got the league. The development of football in Europe began from England that played in the middle 19 ages at school. Then in 1857 there was the first football club in the world, that is Sheffield Football Club. This club is an association school that focused on football in 1863 then football association in England was formed[1]. In a football team needed some supported elements, that is players, coach and official. A football club need a coach. He should give a physical training and a strategy then decide the team formation that will be applied on the match. The players quality determines the strength of a team. It would be very difficult for a team to choose the players if there is not a proper standard on choosing[2]. Beside that, need an accuracy in assesing the ability of a player, so he can be eligible to join the team and increase the team's achievements. It is not uncommon for factors like and dislike to be decisive in choosing players and not based on player's ability. Sometimes it makes the coach or team manager choose the wrong player and after a while the player is dumped because he does not show a good game. It is unfortunate when the price of the players is very expensive but the player does not show comparable result. [3][4]States that when modern football initiated for the first time then disseminated by Englishmen to the world, maybe there was no one think that it would influence aspects of world life. Football may be just a game, but the game effects have far expanded into other areas such as religious social, information technology, entertainment, politics, and even

ICCSET 2018, October 25-26, Kudus, Indonesia

Copyright () 2018 EAI

DOI 10.4108/eai.24-10-2018.2280564 
the economy. In the football industry is not easy to form a team, the quality of a team can be judged by the ability of each player.

The issues that will be discussed on this paper is El Faza Football School where it is a football team that has good achivement. El Faza is the sixth standings position on PSSI Surabaya competion. SBB will produce football player generation that has a good quality. This system is created on El Faza Football School, the authors hope this system can make it easier to determine the position of the players so it produce a good and quality football team and win the game. This system can also help determine what kind of deficiencies and types of players are needed in the team so El Faza Football School will produce high quality football players. The steps of calculations such as research results from [5] [6]i.e. the first phase determines the number of criteria is used, where the criteria that will be used later on, namely: 1) Dribbling that has sub criteria such as jugling drible, straight, zig-zag drible, 2) Speed have sub criteria run $30 \mathrm{~m}$ and run $12 \mathrm{~m}, 3$ ) Passing has sub criteria passing down, passing over, control over, and under the control, 4) Headings have sub criteria on static and for the jump, 5) Shoot have the sub criterion chip kick and shoot. After it determines the weighting on each criterion by using the 1-100 interval for the most important priority, calculate the normalization of each criterion by comparing values and quantity of weighting criteria, provide parameter values on each criterion for each alternative, determine the value of them by converting each criteria to raw data value, at least determine the final value of each criterion by diverting the normalization value of raw data criteria and weighting criteria[7]. Then total the values from multiplication. From the calculation would be known weights of each player and also determine the players suitable position.

\section{Methodology}

\subsection{Simple Additive Weighting}

SAW (Simple Additive Weighting) method known as weighted sum method. The basic concept of method is to find a weighted summation of rating performance on any alternative on all attributes [8] and [9]. SAW (Simple Additive Weighting) method need a decision matrix normalization $(\mathrm{x})$ process to a scale that can be compared with all the alternative rating. This SAW (Simple Additive Weighting) method requires decision makers to input weights to each attribute. The total score for the alternative is obtained by summing all the results of the multiplication between the ratings (which can be compared across attributes) and the weight of each attribute. The rating of each attribute must be dimensionless that has passed normalizing matrix process. The decision-making process is to choose an alternative. SAW (Simple Additive Weighting) method is often known as weighted sum method. According [9] research steps in using the method SAW (Simple Additive Weighting), are :

1. Determine the criteria that will be the reference in decision making.

2. Determine the match rating of each alternative on each criterion.

3. Make decision matrix based on criterion ( $\mathrm{Ci}$ ), then do normalization of matrix based on equation which is adjusted to attribute type (attribute of profit and cost) so obtained by normalization matrix.

The final result is obtained from each ranking process that is the sum of normalized matrix multiplication $\mathrm{R}$ with vector weight to obtain the biggest value chosen as the best alternative. 


$$
r i j=\left\{\frac{X i j}{\operatorname{Max} X i j} \frac{X i j}{\operatorname{Min} X i j}\right\}
$$

If $\mathrm{j}$ is benefit attribute

If $\mathrm{j}$ is cost attribute

Where :

rij : Normalized rating performance

Maxi : Maximum value from each row and collum

Mini : Minimum value from each row and collum

Xij : Row and collum of matrix

Rij is normalized rating performance of alternative $\mathrm{Ai}$ on $\mathrm{Ci}$ attribute; $\mathrm{i}=1,2, \ldots \mathrm{m}$ and $\mathrm{j}=1,2, \ldots, \mathrm{n}$. Preference value for each alternative $(\mathrm{Vi})$ is :

$$
V i=\sum_{j=1}^{n} W j r i j
$$

Where :

$\mathrm{V} i \quad$ : Alternative final value

Wi : Weight

Rij : Normalized matrix

The bigger $\mathrm{V} i$ value indicates that alternative $\mathrm{A} i$ is better[10].

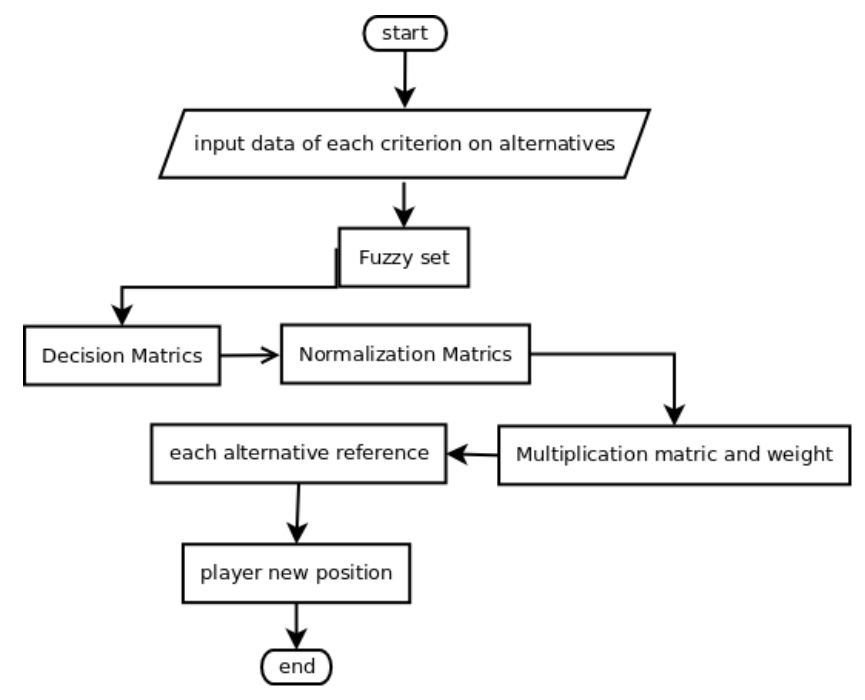

Fig. 1. Calculation Flowchart of Fuzzy SAW.

Figure 1 is flowchart of Fuzzy SAW method system that explain the steps, that are :

1. Input the criteria value of each alternative and the saved data is directly entered into the database. 
2. In this process, input value is not a real value but it is the absolute value that will be processed in the system.

3. Create a decision matrix based on criteria.

4. Normalizing matrixs based on the equations

5. Multiplication of the normalized matrix value and weight

6. A new playes position as the final value

\section{Result and Discussion}

\subsection{Result}

The result of this research were taken 18 players to test data where players play in positions that have been recommended by system and compared with the result of coach observations. The coach can take the final decision of the test. Here is a table of test results that have been done.

Table 1. Test Result.

\begin{tabular}{cccc}
\hline Player Name & System & Coach Analysis & Result \\
\hline Alfan Qirom & WM & WM & True \\
Ardi Febrian & AMC & AMC & True \\
Azrul Ananda & DMC & Bek & False \\
Ilham Zainal & AMC & WM & False \\
Naufal Zidane & CM & CM & True \\
Billy Andri & WM & AMC & False \\
Kelvin Ardiansyah & CM & CM & True \\
David Setiawan & DMC & Bek & False \\
Lukas Ardiansyah & AMC & DMC & False \\
Fery Widyatama & DMC & DMC & True \\
Moch.Sofyan & WM & WM & True \\
Kael M.Santos & CM & CM & True \\
Rifqy Ardiansyah & AMC & AMC & True \\
M.Fauzan & AMC & CM & False \\
Febri Yuri Eka & DMC & CM & False \\
Kresna Fajar & CM & Striker & False \\
Novan Awan & DMC & AMC & False \\
Yoga Endik & DMC & DMC & True \\
\hline
\end{tabular}

Table 1 is test result that has been done to get accuracy of system. There are 3 collum that contain player's desire, first desire of the players when going into the football school. System collum is the result of calculation thas has been done by system. Coach collum is the result of coach own observations. Then those 3 columns are taken conclusion by calculating test percentage value. Based on table 1 known that only taken 9 from 18 players who correspond between the system and coach analysis. First player position compared with system 
recommendation then the system gives to the coach to analyze whether in accordance with the expected position. The system produce accuracy about $50 \%$ so that the system can be good unough to use for determining position. Based on that test result generated recommendation a middle position where the middle position devided into some sub positions, that are :

1. AMC, is a position where the players role as a regulator of the attack in a game of football.

2. $\mathrm{CM}$, is the position where the player role is distribute the ball to the player and maintain balance of the team.

3. DMC, is the position where the players role to stop attack of the opponent.

4. WM, is the position where the players role is helping an attack on either sideline.

\subsection{Discussion}

The analysis of this system uses the testing data training results that obtained at SSB EL FAZA Surabaya. The data taken will be compared to the data recommended by the trainer. By entering the value of the exercise with the form below then obtained the final value to be entered into the test table.

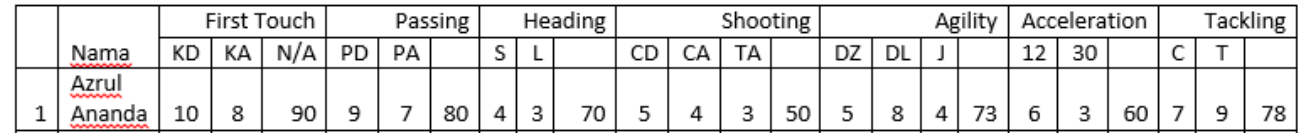

Fig. 2. Training Form.

Figure 2 is one of data from SSB El Faza that used to be sample.

a. Players data by criteria

Table 2. El Faza players data,

\begin{tabular}{llllllll}
\hline Nama & F_touch & Tackling & Pass & Head & Shoot & Agility & accel \\
\hline Azrul & 90 & 78 & 80 & 70 & 50 & 72 & 60 \\
\hline
\end{tabular}

Table 2 is one of El Faza players data that used to be sample.

b. Give a weight for each criteria

Table 3. Weight Criteria.

\begin{tabular}{llllllll}
\hline Nama & F_touch & Tackling & Pass & Head & Shoot & Agility & accel \\
\hline Azrul & 1 & 1 & 0.8 & 0.75 & 0.5 & 0.75 & 0.75 \\
\hline
\end{tabular}

Table 3 is a data conversion of each criteria. 
c. Normalization Process

Table 4. Normalization

\begin{tabular}{llllllll}
\hline Nama & F_Touch & Tackling & Pass & Head & Shoot & Agility & accel \\
\hline Azrul & 1 & 1 & 0.8 & 0.75 & 0.5 & 0.75 & 0.75 \\
\hline
\end{tabular}

Table 4 is a normalization process that taken form weight data with the maximum value of each criteria.

d. Final Value

Table 5. Final Value.

\begin{tabular}{llllllll}
\hline Nama & F_touch & Tackling & Pass & Head & Shoot & Agility & accel \\
\hline Azrul & 0.1 & 0.15 & 0.16 & 0.125 & 0.075 & 0.075 & 0.125 \\
\hline
\end{tabular}

Table 5 is the final value that taken from multiplication every value and weight then both of them summed up to be a final value.

\section{Conclussion}

From the results and discussion above can be concluded that this system is quite effective for helping the coach to determine the position of new players. This is evidenced by the results of test that show the assessment between the observation of a trainer with the system there are similarities that serve as a reference in determining the new position of players that is equal to $50 \%$.

\section{References}

[1] Supriyono, Hamdani, and A. Septiarini, "Sistem Pendukung Keputusan Pemilihan Formasi Sepakbola dengan Berbasis Web Studi Kasus: Persisam Putra Samarinda,” J. Ilm. Mustek Anim, vol. 2, 2013.

[2] M. G. T. Putra and Rusli Muhammad, "Arrangement of Players Position in Soccer Using The Technique of Naïve Bayes," ComTech, vol. 6, 2015.

[3] H. Alprianta, Anton Setiawan H, and Yuliani Indrianingsih, "Sistem Pendukung Keputusan untuk Menentukan Posisi Pemain Ideal Dalam Tim Sepakbola dengan Metode Algoritma Genetika," STTA Yogyakarta, vol. 2, 2012.

[4] Rokhmat Taufiq Hidayat, "Analisis Atas Proses Bisnis Klub Sepak Bola di Liga Eropa,” FE Univ. Indones., 2010.

[5] A. M. Kunevi and T. G. Laksana, "Sistem Pendukung Keputusan Posisi Striker Ideal dalam Strategi Sepakbola di Bina Putera Menggunakan Metode SAW," J. Online ICT STMIK IKMI, vol. 14, 2015. 
[6] S. Timo, Kurikulum \& Pedoman Dasar Sepak Bola Indonesia. malang, 2005.

[7] Prasetyo, Sigit Karisma Utomo, Kurniawan, and Praditya, "Sistem Penunjang Keputusan dalam Pemilihan Pemain Untuk Posisi Tertentu Pada Sepak Bola," Semin. Nas. Teknol. Inf. dan Multimed., 2016.

[8] Helilintar, Risa, Wahyu, Wing Winarno, A. Fatra, and Hanif, "Penerapan Metode SAW dan Fuzzy dalam Sistem Pendukung Keputusan Penerimaan Beasiswa," Citec J., vol. 3, 2016. [9] Radhitya, Yoga, Nur Hakim, Fitro, Solechan, and Achmad, "Sistem Pendukung Keputusan Penentuan Penerima Beasiswa dengan Metode SAW," J. Speed, vol. 8, 2016.

[10] E. Turban. et al, Introduction to Information Technology. John Willey \& Sons, Inc, 2005. 